\title{
Understanding Canoe Making as a Process of Preserving Cultural Heritage
}

\author{
Debora Peterson $^{1^{*}}$, Natalia Hanazaki ${ }^{2}$, and Fabiana $\mathrm{Li}^{3}$ \\ ${ }^{1}$ Natural Resources Institute, University of Manitoba, Winnipeg, Canada. ${ }^{2}$ Department of Ecology and Zoology, Universidade \\ Federal de Santa Catarina, Florianópolis, Brazil. ${ }^{3}$ Department of Anthropology, University of Manitoba, Winnipeg, Canada. \\ *deborapeterson@yahoo.com.br
}

\begin{abstract}
Canoes are deeply ingrained elements of the Caiçara culture, not only for their historical and current practical uses, but also for their socio-cultural outcomes. Caiçara people are the descendants of Europeans, Africans, and Indigenous peoples who inhabit parts of the Atlantic Forest in the southern and southeastern coast of Brazil. Despite this, canoe making has been declining in several Caiçara communities, while many ongoing initiatives have attempted to encourage the maintenance of this practice. This article explores some of the Caiçara-canoe relationships within the Juatinga Ecological Reserve, in southeastern Brazil. We discuss how canoes are an appropriate technology for some fishing techniques, and are thus not easily replaced by fiberglass or aluminum boats. We also explore some socio-cultural dimensions of canoe making in light of the relationships of Caiçara canoe makers and fishers with the forest and with other community members. This article contributes to a growing body of knowledge to protect elements of Caiçara identity, including initiatives to help maintain canoes, canoe making, and the people involved with them.
\end{abstract}

Received January 1, 2019

OPEN ठACCESS

Accepted June 24, 2019

DOI 10.14237/ebl.10.1.2019.1363

Published August 6, 2019

Keywords Ethnoecology, Food security, Traditional knowledge, Caiçara, Brazil

Copyright (c) 2019 by the author(s); licensee Society of Ethnobiology. This is an open-access article distributed under the terms of the Creative Commons Attribution-NonCommercial 4.0 International Public License (https://creativecommons.org/licenses/by-nc/4.0), which permits non-commercial use, distribution, and reproduction in any medium, provided the original author and source are credited.

\section{Introduction}

Dugout canoes have special significance as a cultural product for local, traditional, and Indigenous peoples worldwide (Gilmore et al. 2002; Orofino et al. 2017). They are a means of transportation of people and goods in more remote areas, where access by land is often difficult. They also play an important role in the subsistence of small-scale fishers who depend on them to ensure their food security. Despite this, researchers have been reporting declines in the practice of canoe making, with concerns that the traditional knowledge associated with this cultural practice may get lost or eroded. The decline of canoe making is related to the complexity of this skill (Lee et al. 2001), the lack of access to natural resources (Paula et al. 2019), the increase of aluminum boats (Orofino et al. 2017), the influence of Western education (Brosi et al. 2007), and the discouragement the youth face when learning this practice (Németh 2011). All these issues relate to the current scenario in Paraty, on the southeastern coast of Brazil, where local communities of Caiçara people inhabit the Atlantic Forest (a region with high biodiversity). Over the past 40 years, with the intensification of tourism and urbanization, and the establishment of protected areas, Caiçara communities have been expressing their concerns to maintain their rights to their traditional territory and cultural practices, including canoe making.

Multi-scale initiatives involving policy makers, researchers, and Caiçara have emerged to help protect this practice. At the policy level, Caiçara canoes were recognized as tangible and intangible cultural heritage of the Rio de Janeiro State (IPHAN 2013; Rio de Janeiro 2016), and an ongoing process seeks to recognize them as part of the intangible cultural heritage in Brazil (Németh 2011). Researchers have generated knowledge on aspects of canoes and canoe making and called social media users to identify canoe makers in a collaborative digital map ${ }^{1}$ (Denadai et al. 2009; Maldonado 2004; Németh 2011). Community- 
based initiatives, such as canoe racing, also help raise awareness of the significance of canoes for Caiçara identity.

This article aims to contribute to current initiatives to maintain the Caiçara cultural practice of canoe making. Researchers have documented the cultural practices associated with canoe making, favored tree species, and canoe-related stories (Denadai et al. 2009; Maldonado 2004; Paula et al. 2019). But there are also other aspects of the Caiçaracanoe relationship that can be highlighted. This article takes an ethnoecological approach to (1) discuss the Caiçara reliance on canoes for specific fishing techniques and food security, (2) examine how canoe making may help maintain people-forest connections, and (3) consider how both canoes and canoe making may help maintain relationships between Caiçara people. The research presented in this article is part of a larger project that aimed to understand how traditional people can participate more effectively in the management of protected areas.

The Juatinga Ecological Reserve, established in 1992, was chosen as the study site due to its current political significance. To comply with the current Brazilian environmental law for protected $\operatorname{areas}^{2}$, the Reserve has been undergoing a process of recategorization into a new protected area status that allows for the sustainable use of resources and participation of traditional people. We employed a set of research methods that included ethnographic fieldwork, semi-structured interviews with canoe makers, participant observation, and a multi-stage photovoice process conducted with members of a Caiçara community in the Juatinga Ecological Reserve. In each corresponding section, the research methods will be described in greater detail along with the results of the study.

\section{The Caiçara people and the Juatinga Ecological Reserve}

The Juatinga Ecological Reserve is located in Paraty, Rio de Janeiro state, in the Atlantic Forest. It is home to approximately 1,500 people, the majority Caiçara. The Caiçara are mixed-heritage descendants of Europeans, Africans, and the Tupinambá Indigenous people, and have for many generations engaged in subsistence activities such as shifting agriculture, subsistence hunting, plant harvesting, basket making, wood carving, and fishing. Their inherited fishing cultural practices include the use of plant fibers to make fishing nets and baskets, the use of numbing plants to capture fish, and carving techniques to make dugout canoes (Mussolini 1980). In a study on the diversity of plant knowledge in Praia do Sono, Brito and Senna-Valle (2012) found that Caiçara participants (men and women) had extensive ethnobotanical knowledge of the plants of this Reserve. People's relationships with the landscape have been influenced over time by the establishment of protected areas, the presence of land grabbers, and the increase of tourism activities in the region. These factors contributed to cultural changes in the communities within the Reserve. Land tenure became a major concern to many Caiçara in the Reserve as land grabbers engaged in legal disputes with them over their traditional land, forcing many people to migrate to other regions in Paraty. The establishment of the Reserve followed a top-down management approach, adding conflicts over traditional land as cultural activities, such as shifting agriculture and hunting, became forbidden. Tourism contributed to changes in the local economy as people became more involved with tourism-related activities (e.g., working and managing local restaurants, camping, and transporting tourists). Other changes (e.g., incorporation of industrialized food in the local diet) were also significant, but for some Caiçara in the Reserve, they play a smaller threat to the Caiçara culture-beliefs, values, social structure, economy, and arts-when compared to former examples (Sinay et al. 2019). Changes in technology are also evidenced by an increasing number of fiberglass or aluminum boats in the communities. Sinay et al. (2019) reported that all adult men of one community in the Reserve (Martim de Sá), had changed their canoes to motorized fiberglass or aluminum boats by 2015 to facilitate access to markets and tourists in Paraty.

\section{Caiçara Canoes: An Appropriate Technology}

Photovoice is a participatory method which involves providing people with cameras and asking them to identify and represent images that illustrate their own reality (Castleden et al. 2008). Photovoice was conducted with six Caiçara participants with diverse roles_artisan, community leader, small-scale farmer, church representative, park ranger, environmental educator, and local tourism guide- in Praia do Sono, a community located in the Juatinga Ecological Reserve (for a detailed description of photovoice data collection see Peterson et al. under review-a). Praia do Sono was chosen because it has the easiest access to downtown Paraty, which facilitated photo printing, 

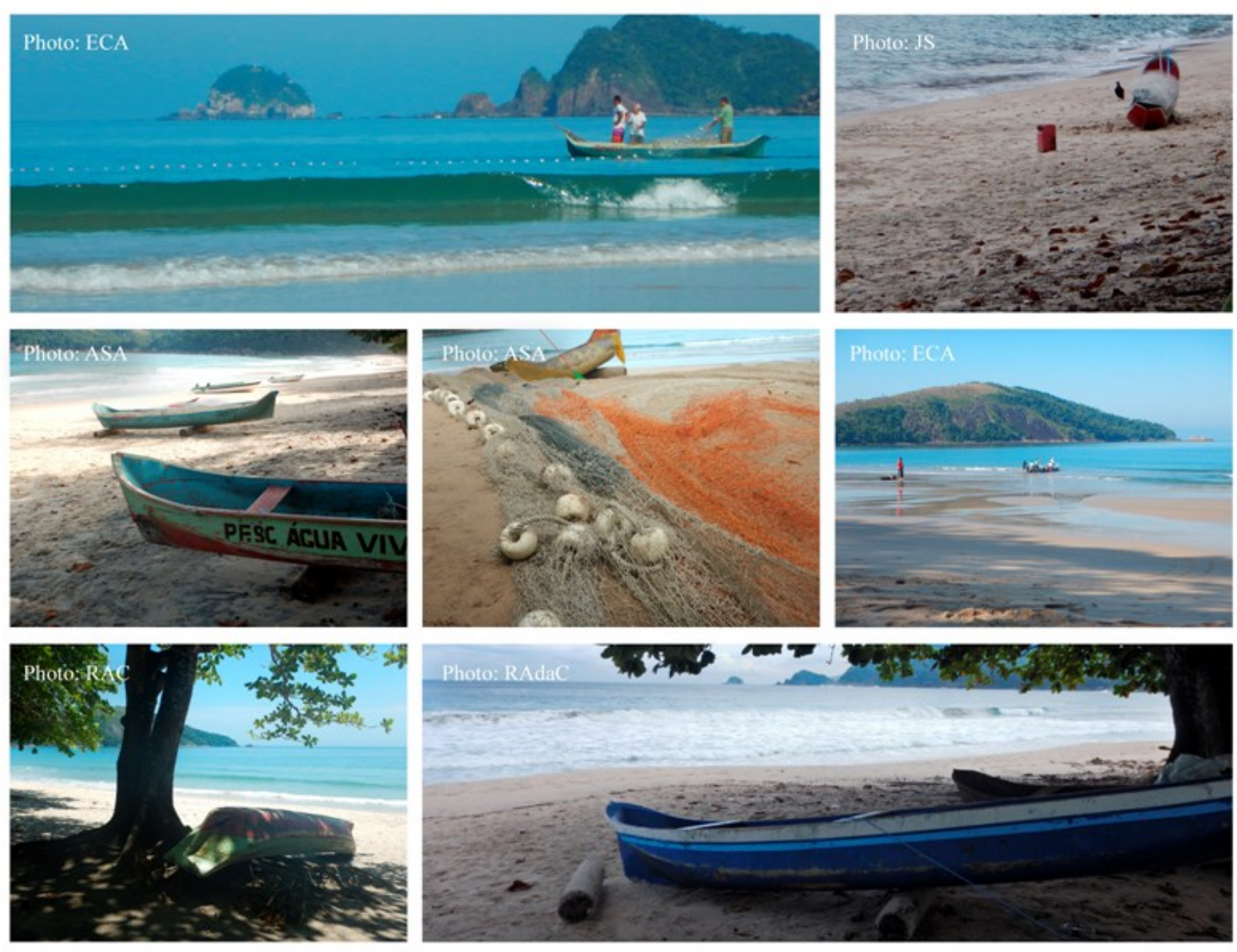

Figure 1 Photos of canoes taken by photovoice participants of the Praia do Sono community in the Juatinga Ecological Reserve (2015-2017).

and it is probably the most impacted community by tourism expansion in the Reserve. Participants were selected based on the following factors: (1) time living in the community or around the Reserve (at least 10 years), (2) willingness to take part in this research, (3) interest in photography, and (4) interest in talking about conservation. The participants were asked to take photos in response to the research question: What do you understand as conservation? Photos were then used to guide individual interviews with participants. The word "canoe" was the second most cited ( $n=$ 254) in the photovoice process, surpassed only by the word "community." From the 44 photos chosen by participants to prompt photovoice interviews, seven photos portrayed canoes (Figure 1). Participants used these photos to talk about the cultural significance of canoes, the practice of passing canoe making knowledge to youth, and the aesthetics of canoes in their landscape.

When asked why canoes are so significant for the Caiçara people in the Reserve, one participant remembered that, in the past, they were the only means to bring goods to some places in the Reserve. This participant noted that the transportation of goods would still rely on canoes if they did not have access to fiberglass boats. The Juatinga Ecological Reserve is a remote peninsula, and access to most of the eight communities and twelve smaller settlements located there is difficult (Figure 2). There are no roads connecting these communities, so people walk to them on trails or access them by sea. 


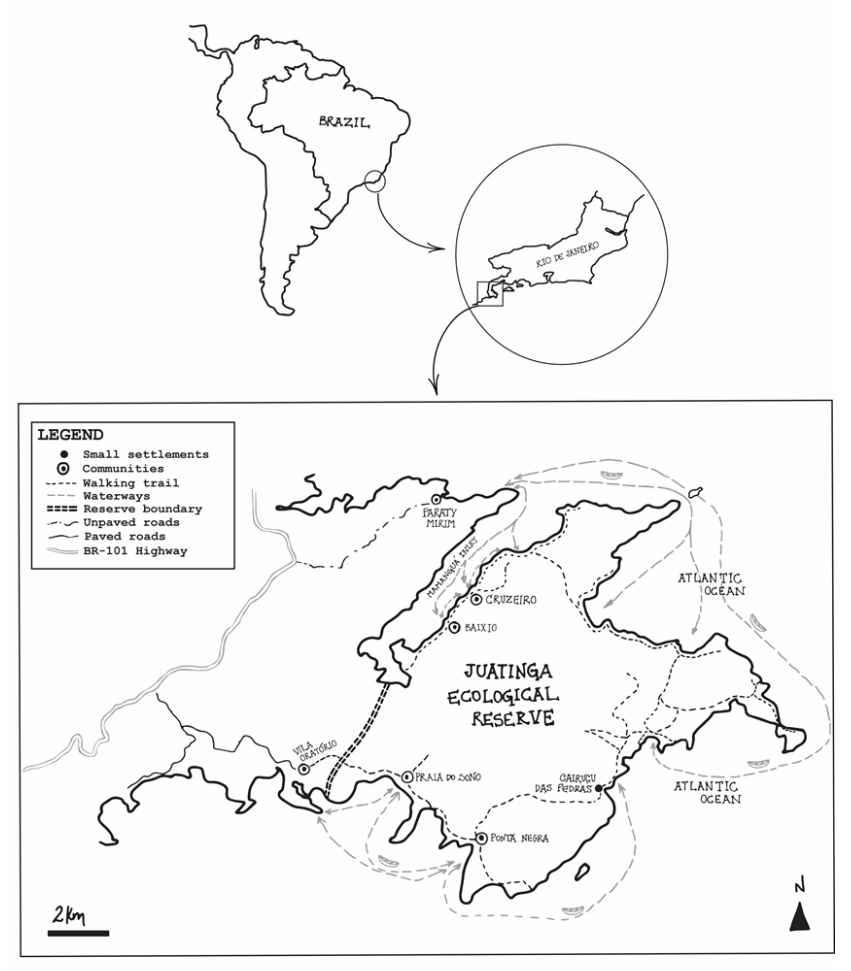

Figure 2 Main walking trail (bold dashed line) and waterways (grey dashed line) to access communities and small settlements (with less than 50 people) within the Juatinga Ecological Reserve. Paraty Mirim and Vila Oratório are important communities as they are close to the Reserve and have access road to downtown Paraty. Map prepared by G. G. Orofino.

The seascape is a variable environment that impacts people-canoe relationships. Sheltered or open waters influence the characteristics of canoes (and paddles), while the availability and behavior of the fish species influence fishing practices. The northern communities of the Reserve are mostly in sheltered waters, in an inlet called Mamanguá. Although subjected to high variation in sea tides, this inlet has mostly good navigation conditions. Fiberglass and aluminum boats, as well as canoes, are important for both fishing and transportation within this inlet. In Mamanguá one can find small canoes $(\sim 2-3 \mathrm{~m})$ used for traveling from the docks to anchored canoes within the inlet; canoes for other fishing techniques $(\sim 4-5 \mathrm{~m})$, and canoas de voga, the biggest canoes (more than $7 \mathrm{~m}$ ), used mostly for the transportation of goods. The southern communities, in contrast, are in the open sea, often facing rough sea conditions. In these communities, fiberglass and aluminum boats are currently used for transportation and sometimes for fishing, whereas canoes are commonly used for squid, mullet and $\operatorname{cerco}^{3}$ fishing. Squid jigging canoes are the smallest $(\sim 3-4 \mathrm{~m})$, canoes for mullet fishing are slighted bigger $(\sim 4-5 \mathrm{~m})$, and canoes for cerco fishing are the biggest ones $(\sim 5-7 \mathrm{~m})$.

As the tradition of canoe making is declining, many people see canoes slowly giving way to more modern watercraft, such as motorized fiberglass and aluminum boats. Although this may be a possible scenario for some places, in the Reserve the Caiçara canoes were mentioned as the best technology for some of the local fishing techniques, mullet fishing being one example. The mullet fishing happens every year from May to August with social, economic, and cultural importance for fishers in the southern and southeastern coast of Brazil (Abreu-Mota et al. 2018). Canoes with paddle propulsion are more suitable to surround the mullet schools because they are more silent than motorized fiberglass boats. A photovoice participant (Translated here and elsewhere by DP) explained this:

...with mullet, with any fish species... it is difficult to go fishing with the engine working. Because it [the school of fish] submerges and goes away. In this way, the canoe is better for this fishing technique. Because it is not noisy, they [fishers] go out fishing with paddles. The [sound of the] engine frightens the fish... Fishers [in fiberglass boats] will not surround them [the schools]. They use the fiberglass boat to cover larger distances... And for when they use tangle nets... They place it one day and go visit it one day later. To surround a mullet school... you cannot use the engine, you cannot make noises.

These ideas relate to the notion of appropriate technology, which implies that technology should serve the needs of people (Schumacher 1973) — in this case, the need for a silent watercraft. Furthermore, Caiçara canoes are small, simple, capital-saving, usercentered, and have a sustainable approach, which comply with Schumacher's criteria for appropriate technology (1973).

Similarly, the Waimiri Atroari Indigenous people from the Amazon found aluminum boats unsuitable for fishing with bows and arrows in the flooded forest (Milliken et al. 1992). Part of this unsuitability was 
Table 1 Key references on canoe making with number of species used by each group.

\begin{tabular}{lll}
\hline & \multicolumn{2}{l}{ Number of species used } \\
Setting and human group & for canoe making & Key References \\
\hline Búzios, Brazil - Caiçara & 7 & Begossi et al. 1993 \\
Amazonia, Brazil - Waimiri Atroari & 10 & Milliken et al. 1992 \\
Ubatuba, Brazil - Caiçara & 25 & Maldonado 2004 \\
Paraty, Brazil - Caiçara & 7 & Borges and Peixoto 2009 \\
Ubatuba, Brazil - Caiçara & 20 & Denadai et al. 2009 \\
Paraty, Brazil - Caiçara & 6 & Brito and Senna-Valle 2012 \\
Multiple cities, Brazil - Azorean descendants & 18 & Roque 2017 \\
Multiple cities, Brazil - Caiçara and Azorean descendants & 42 & Paula et al. 2019 \\
Paraty, Brazil - Caiçara & 14 & This study \\
\hline
\end{tabular}

related to the size of these boats and the difficulty of maneuvering them in that environment. Small canoes were found to be more appropriate to the Waimiri Atroari because they enabled fishers to approach the prey without ripples or noises, which may scare the fish away. As fish was the major source of protein for them, having the appropriate technology was imperative to assure their daily diet (Milliken et al. 1992).

Orofino et al. (2017) found no consensus for the preference in watercraft among the Azorean descendants of southern Brazilian coast. They found that some people favored canoes due to their properties, such as buoyancy, perceived safety advantage, and quietness, which facilitates fishing. In contrast, other people preferred the fiberglass or aluminum boats due to their easier maintenance and because there was no need for environmental authorizations to access the trees and no dependence on the few canoe makers to obtain a vessel.

\section{Canoe Making: People-Forest Connections}

People-forest connections are influenced by the degree of exposure people have to forest resources, which in turn, can contribute to greater ethnoecological knowledge. As an example, women, who are usually more involved with traditional medicine, retain greater knowledge of medicinal plants than men (Aswani et al. 2018). On the other hand, men highly engaged with forest activities usually retain greater knowledge of forest resources than women do (Aswani et al. 2018).

The ethnoecological knowledge of tree speciessuch as the ability to identify suitable species for canoe making - and peoples' observations of forest dynamics may reveal how canoe making influences people-forest connections. Table 1 shows the number of species used for canoe making by various communities in Brazil, displaying a range of six to 42 species of trees. In this study, participants cited a higher number of species for canoe making than what was previously found in the literature for the Reserve (Brito and Senna-Valle 2012). Canoe makers cited 14 tree species suitable for every type of canoe needed in the Juatinga Ecological Reserve. Purposive sampling may have contributed to this as the method helped select Caiçara with knowledge of resources for, and practice in, canoe making specifically. In addition, the snowball method helped identify other participants with a similar profile within Praia do Sono, three other communities (Ponta Negra, Cruzeiro, and Baixio), and one small settlement (Cairuçu das Pedras), covering different locations in the Reserve. Twelve canoe makers took part in semi-structured interviews with questions regarding preferences for resources, landscape use, knowledge of forest resources, and knowledge transmission. Ethnographic fieldwork was conducted with five canoe makers, who helped to identify species, allowing for participant observation and partaking in local experiences in the forest. Plants used for canoe making were identified with the help of specialists and the literature (e.g., Flora do Brasil 2020).

The knowledge held by canoe makers is valued by other Caiçara people. One photovoice participant used a photo (Figure 1) to talk about this knowledge as necessary for conservation:

...They [canoe makers] end up creating several, several things so they do not take the tree in the [wrong] moon, because otherwise it [the canoe] will rot. It seems like a way [to say] to you not to make it [wrong], to respect. But everything has a certainty. Everything has a certainty in what they are talking about. 
Regardless of the way it is being talked about. It has to be [made] sort of exactly how they say, otherwise it does not work. A canoe, for example, will not last years if you take out the tree during the time that is not good for removing the tree. It [the knowledge] is not taught as a rule, it is taught with stories, it is passed on through stories. This is certainly why we have everything there, due to this teaching process, right? This is part of the way it is today, the way it is preserved... Because it is what we have said, they know exactly where the trees are. They know what is there and where they are keeping them, which is as if they were keeping them [the trees]. To conserve is for them a way of keeping them.

People observe potential trees for canoe making as they journey through the forest. They monitor their growth, their health, the abundance of certain species, and any possible natural or human disturbances. One community member, for instance, called attention to a xylophage white larvae that has been eating the wood of one of the significant species for canoe making in the region, the Sclerolobium denudatum (ingá-amarelo in Portuguese). As trees of this species are being attacked by these larvae, he is concerned with what may happen with the affected trees. He made other canoe makers aware of the presence of these larvae, asking them to monitor the $S$. denudatum in the forest whenever possible. This resembles a disturbance that occurred in past years, which was mentioned by some participants, where the trees of Schizolobium parabyba (garapuvu in Portuguese), started dying in the region. People noted the disturbance but did not know the reason for the mortality. In their research, Callado and Guimarães (2010) estimated that climatic anomalies were most likely the responsible factors for the mortality of $S$. parabyba on an island near the Reserve.

The ecological knowledge that is built from people-forest connections can contribute to forest conservation. The local forest management practices, such as selecting a tree that best fits the canoe maker's needs, and the local observations of potential forest disturbances and alterations within the landscape, such as the presence of xylophagic pests in trunks are some examples of how this knowledge can provide insights for local conservation.

\section{Caiçara Canoes and Canoe Making: People- People Connections}

Canoe making may also contribute to social connections within the Caiçara community. This was noted by the specialists of the Instituto do Patrimonio Historico e Artístico Nacional (National Institute of Historic and Artistic Heritage) as the reason why Caiçara canoes should be considered as intangible cultural heritage in addition to tangible cultural heritage (IPHAN 2013). One of the best-known social events related to canoe making is the puxada de canoa (also called mutirão), a collective effort (usually carried out by the canoe maker's friends and relatives) to pull the pre-shaped tree trunk down from the forest (Peterson et al. under review-b). There are, however, other cultural dimensions of canoes and canoe making that are important to acknowledge.

First, canoe making encourages people to plan and organize cultural events such as canoe racing (Denadai et al. 2009). These events have been important to reunite Caiçara people from communities along the Brazilian coast and partaking in these meetings contributes to the development of social cohesion and a Caiçara identity. In August 2018, Praia do Sono had its first canoe racing with men, women, youth, and children from different communities participating in different categories. Second, local stories are told by community members about canoes and canoe making. Some of them relate to adventures in the canoe making process, others about experiences during fishing or transport, and yet others follow the history of canoes inherited through generations. The practice of telling stories helps to disseminate environmental knowledge and local guiding principles across generations and between members of communities (Berkes 2018), and it is advocated as a tool for biodiversity conservation practice (Fernández -Llamazares and Cabeza 2018). Third, canoes have aesthetic and recreational value for community members in the Reserve's landscape, which are within ecosystem cultural services, and contribute to people's well-being (Millennium Ecosystem Assessment 2005). Finally, the exchange of knowledge among community members is important to the exchange of information between harvesters about potential trees for canoe making in the landscape. Evidence of such exchange was mentioned by Peterson et al. (under review-b) in regard to Caiçara people in the Reserve. 
As people often conduct different harvesting activities, which requires the use of multiple forest habitats within the Reserve, their knowledge of the resources in the forested landscape may vary, and these variations may help canoe makers and others to access resources from different locations.

\section{Conclusions}

This article highlights some of the reasons why canoes and canoe making should be encouraged among traditional and Indigenous peoples in this Reserve and elsewhere. There are fishing techniques that cannot be performed with motorized fiberglass or aluminum boats because they are noisy and less maneuverable. Hence, these boats are not entirely a substitute for dugout canoes. Fishing is the most important livelihood activity for food security in Paraty (Hanazaki et al. 2013). In the Reserve, the use of canoes to fish for mullet and other species provides the Caiçara with a diet staple and livelihood diversification. If canoes are not available in the Reserve, fishers will have to search for them elsewhere, or even change some fishing practices. Caiçara canoes are an important component for cultural practices and are fundamental to a Caiçara identity. Thus, they need to be protected as a tangible cultural heritage associated with an immaterial knowledge. A diversity of initiatives can help to protect them. For example, intergenerational activities involving the elders and youth could be implemented to restore and paint the existing canoes. Such measures can extend the lifetime of canoes but are sometimes not taken because of the price of these services.

Canoe making also needs to be protected as intangible cultural heritage. The complex process of canoe making requires knowledge of the best trees for carving, the availability of resources in the landscape, and the local regulations governing access to these resources. This detailed knowledge, along with some of the people-forest connections, may get eroded, as has been happening elsewhere (Orofino et al. 2017). As canoe makers are the ones who have the practical skills, theoretical knowledge, and canoe making techniques, they should participate in the different processes of canoe protection that seek to encourage the sustainability of this cultural practice-for instance, educational actions with youth, and meaningful participation in policy decisions regarding the legal use of trees in the Reserve.
The combination of different knowledge systems (e.g., traditional and academic) can contribute to efforts to maintain the cultural aspects of canoe making and encourage conservation. One way to do this is through knowledge co-production, a collaborative process that aims to use the range of knowledge available to help solve problems (Armitage et al. 2011; Tengö et al. 2014). As this research shows, Caiçara forest knowledge can provide clues that can help researchers to investigate forest dynamics in the Atlantic Forest, a region that demands substantial conservation efforts. This combination of knowledge systems may prompt better ecological and social outcomes in the management of resources, especially in the case of protected areas. Our findings illuminate how canoe making contributes to practices that shape peoples' landscape, identity and food security. Given that many Caiçara communities have had their resources curtailed for conservation reasons, our findings are particularly important to support Caiçara peoples' rights to access forest resources that are significant to maintain the local practice of canoe making.

\section{Notes}

1This collaborative map is online: https:/ / tinyurl.com/yywgznq5. Accessed on May 28, 2018.

2The SNUC law stands for Sistema Nacional de Unidades de Conservação and was enacted in July 2000. This law regulates the Brazilian protected areas and divides them into 12 categories (five strictly protected areas and seven sustainable use areas), depending on the objectives of protection, land tenure, use and management of resources, research and tourism activities. As the "Ecological Reserve" category was not included in the SNUC law, the Juatinga Ecological Reserve needs to be recategorized.

${ }^{3}$ Cerco is a stationary fishing technique brought into the Juatinga Ecological Reserve by Japanese immigrants in the 1970s-1990s (Mussolini 1980).

\section{Acknowledgments}

We would like to thank the participants from the Juatinga Ecological Reserve who shared their knowledge and provided their valuable time to this research. This study was financed in part by the Conselho Nacional de Desenvolvimento Científico e Tecnológico (CNPq) - 444343/2014-8 and by the Coordenação de Aperfeiçoamento de Pessoal de Nível Superior - Brazil (CAPES) - Finance Code 001. D. P. 
thanks to CAPES, OAS and IDRC/CRC for funding for Doctoral Research and for fieldwork. N. H. thanks to $\mathrm{CNPq}$ for a research productivity scholarship (309613/2015-9). We thank to I. J. Davidson-Hunt, C. J. Idrobo, F. Berkes and V. S. Fonseca-Kruel for early insights and discussions. We thank to L. L. de Paula, G. G. Orofino, R. H. Ludwinsky, T. V. Roque for sharing their knowledge in field and laboratory, and P. Fiaschi for helping with plant identification. Specimens were deposited in the Herbarium FLOR at the Federal University of Santa Catarina and the Herbarium EAFM of the Federal Institute of Science and Technology of Amazonas, in Manaus.

\section{Declarations}

Permissions: This project was approved by the Research Ethics Board of the University of Manitoba (JFREB J2012:155) and INEA, the state governmental agency that regulates the Ecological Juatinga Reserve (Research Permit INEA 051/2015). The ethics code protocols of the International Society for Ethnobiology were followed throughout the research process. Informed consent was obtained from research participants prior to data collection.

Sources of funding: This study was financed in part by the Conselho Nacional de Desenvolvimento Científico e Tecnológico (CNPq) - 444343/2014-8 and by the Coordenação de Aperfeiçoamento de Pessoal de Nível Superior - Brasil (CAPES) - Finance Code 001 (doctoral research award to DP), Organization of American States (OAS) for funding for fieldwork, CNPq (productivity grant for NH 309613/2015-9), the IDRC/CRC International Research Chairs Initiative (A. Begossi/F. Berkes), and the Canada Research Chairs Program (http:/ / www.chairs.gc.ca).

Conflicts of Interest: None declared.

\section{References Cited}

Abreu-Mota, M. A. D., R. P. Medeiros, and R. P. Noernberg. 2018. Resilience Thinking Applied to Fisheries Management: Perspectives for the Mullet Fishery in Southern-Southeastern Brazil. Regional Environmental Change 18:2047-2058. DOI:10.1007/ s10113-018-1323-9.

Armitage, D., F. Berkes, A. Dale, E. KochoSchellenberg, and E. Patton. 2011. Co-management and the Co-production of Knowledge: Learning to Adapt in Canada's Arctic. Global Environmental
Change 21:995-1004. DOI:10.1016/ j.gloenvcha.2011.04.006.

Aswani S., A. Lemahieu, and W. H. H. Sauer. 2018. Global Trends of Local Ecological Knowledge and Future Implications. PLoS ONE 13:e0195440. DOI:10.1371/journal.pone.0195440.

Begossi, A., H. E. Leitão-Filho, and P. I. Richerson. 1993. Plant Uses in a Brazilian Coastal Fishing Community (Buzios Island). Joumal of Ethnobiology 13:233-256.

Berkes, F. 2018. Sacred Ecology. Fourth edition. Routledge, New York.

Borges, R., and A. L. Peixoto. 2009. Conhecimento e Uso de Plantas em uma Comunidade Caiçara do Litoral Sul do Estado do Rio de Janeiro, Brasil. Acta Botanica Brasilica 23:769-779. DOI:10.1590/S010233062009000300017.

Brito, M. R. de, and L. de Senna-Valle. 2012. Diversity of Plant Knowledge in a "Caiçara" Community from the Brazilian Atlantic Forest Coast. Acta Botanica Brasilica 26:735-747. DOI:10.1590/S010233062012000400003.

Brosi, B. J., M. J. Balick, R. Wolkow, R. Lee, M. Kostka, W. Raynor, R. Gallen, A. Raynor, P. Raynor, and D. Lee Ling. 2007. Cultural Erosion and Biodiversity: Canoe-making Knowledge in Pohnpei, Micronesia. Conservation Biology 21:875879. DOI:10.1111/j.1523-1739.2007.00654.x

Callado, C. H., and R. C. Guimarães. 2010. Estudo dos Anéis de Crescimento de Schizolobium parabyba (Leguminosae: Caesalpinioideae) após Episódio de Mortalidade em Ilha Grande, Rio de Janeiro. Revista Brasileira de Botânica 33:84-91. DOI:10.1590/S010084042010000100008.

Castleden, H., T. Garvin, and Huu-ay-aht First Nation. 2008. Modifying Photovoice for Community-based Participatory Indigenous Research. Social Science and Medicine 66:1393-1405. DOI:10.1016/j.socscimed.2007.11.030.

Denadai, M. R., M. A. O. Gonçalves, D. Olivato, and A. Turra. 2009. Com Quantas Memórias se Faz uma Canoa: A Cultura do Uso e Feitio das Canoas de "Um Só Pau" no Município de Ubatuba, SP. Instituto Costa Brasilis and Instituto Oceanográfico -USP, São Paulo, Brazil. 
Fernández-Llamazares, Á., and M. Cabeza. 2018. Rediscovering the Potential of Indigenous Storytelling for Conservation Practice. Conservation Letters 11:e12398. DOI:10.1111/conl.12398.

Flora do Brasil. 2020. Jardim Botânico do Rio de Janeiro. Available at: http:// floradobrasil.jbrj.gov.br/. Accessed on: July 19, 2018.

Gilmore, M. P., W. H. Eshbaugh, and A. M. Greenberg. 2002. The Use, Construction, and Importance of Canoes among the Maijuna of the Peruvian Amazon. Economic Botany 56:10-26. DOI:10.1663/0013-0001(2002)056[0010:CATUCA] 2.0.CO;2.

Hanazaki, N., F. Berkes, C. S. Seixas, and N. Peroni. 2013. Livelihood Diversity, Food Security and Resilience among the Caiçara of Coastal Brazil. Human Ecology 41:153-164. DOI:10.1007/s10745012-9553-9.

IPHAN. 2013. Instituto do Patrimônio Histórico e Artístico Nacional. Processos e Práticas Culturais Referentes à Canoa Caiçara. Processo: 01450.009444/2012-17. Available at: http:// canoadepau.blogspot.com.br/2013/06/iphan-aceita -como-pertinente-o-pedido.html. Accessed on December 12, 2018.

Lee, R. A., M. J. Balick, D. Lee Ling, F. Sohl, B. J. Brosi, and W. Raynor. 2001. Cultural Dynamism and Change-An Example from the Federated States of Micronesia. Economic Botany 55:9-13. DOI:10.1007/BF02864542.

Maldonado, W. 2004. A Construção Material e Simbólica da Canoa Caiçara em Ilhabela. In Enciclopédia Caiçara (Vol. I). O olhar do Pesquisador, edited by A. C. Diegues, pp. 297-320. HUCITEC, NUPAUB/CEC, São Paulo, Brazil.

Millennium Ecosystem Assessment. 2005. Ecosystems and Human Well-being: Synthesis. Island Press, Washington, DC.

Milliken, W., R. P. Miller, S. R. Pollard, and E. V. Wandelli. 1992. Ethnobotany of the Waimiri Atroari Indians of Brazil. Royal Botanic Gardens, Kew, London.

Mussolini, G. 1980. Ensaios de Antropologia Indígena e Caiçara. Paz e Terra, Rio de Janeiro, Brazil.
Németh, P. S. 2011. O Feitio da Canoa Caiçara de Um Só Tronco: A Cultura Imaterial de uma Nação, em 25 linhas. Dossiê para Instrução de Processo de Registro de Bem Cultural de Natureza Imaterial junto ao IPHAN. Available at: http:// nupaub.fflch.usp.br/sites/nupaub.fflch.usp.br/ files/DOSSI $\%$ C3\%8A\%20IPHAN\%20V14.pdf . Accessed on January 31, 2018.

Orofino, G. G., T. V. Roque, V. S. Fonseca-Kruel, N. Peroni, and N. Hanazaki. 2017. Local Knowledge about Dugout Canoes Reveals Connections Between Forests and Fisheries. Environment, Development and Sustainability 20:2773-2793. DOI:10.1007/s10668-017-0016-8

Paula, L. L., M. Dechoum, V. S. Fonseca-Kruel, N. Tamaio, and N. Hanazaki. 2019. Artisans and Dugout Canoes Reveal Pieces of Atlantic Forest History. PLOSONE 14:e0219100. DOI:10.1371/ journal.pone.0219100

Peterson, D., N. Hanazaki, and F. Berkes. Under review-a. Do We All Speak the Same Language when Talking Conservation? Caiçara Understandings of Conservation in their Landscape. Submitted to Conservation and Society.

Peterson, D., F. Berkes, I. J. Davidson-Hunt, and N. Hanazaki. Under review-b. Caiçara People in Juatinga Ecological Reserve, Brazil: Landscape Ethnoecology of Cultural Products. Submitted to Human Ecology.

Schumacher, E. F. 1973. Small is Beautiful: Economics as if People Mattered. Blond and Briggs, London.

Sinay, L., M. C. F de Sinay, R. W. (Bill) Carter, and F. V. de A. Passos. 2019. Traditional People, Protected Areas and Tourism: A 15-year Brazilian Case Study of Cultural Change. Ambiente \&o Sociedade 22. DOI:10.1590/1809-4422asoc0070r4vu1911ao.

Rio de Janeiro. 2016. Lei 7371 de 14 de julho de 2016. Available at: http://www.normasbrasil.com.br/ norma/lei-7371-2016-rj_326290.html. Accessed on May 28, 2018.

Roque, T. V. 2017. Conhecimento e Uso de Espécies Arbóreas para a Construção e Manutenção de Canoas-de-Um-Pau-Só no Litoral Central de Santa Catarina. Master's thesis, Universidade Federal de Santa Catarina, Florianópolis, Brazil. Available at: https://repositorio.ufsc.br/ 
Ethrobiolocy LetTers $\quad$ Perspectives

handle/123456789/183627. Accessed on May 31, 2018.

Tengö, M., E. S. Brondizio, T. Elmqvist, P. Malmer, and M. Spierenburg. 2014. Connecting Diverse Knowledge Systems for Enhanced Ecosystem Governance: The Multiple Evidence Base Approach. Ambio 43:579-591. DOI:10.1007/ s13280-014-0501-3. 